\title{
Photosynthetic performance index in early stage of growth, water use efficiency, and grain yield of winter barley cultivars
}

\author{
Josip Kovačević ${ }^{1}$, Maja Mazur ${ }^{1}$, Alojzije Lalić ${ }^{1}$, Marko Josipović ${ }^{1}$, Ana Josipovićc ${ }^{*}$, Maja Matoša \\ Kočar $^{1}$, Monika Marković ${ }^{2}$, Jasenka Antunović ${ }^{3}$, and Vera Cesar ${ }^{3}$
}

Repetitive heat and drought stress conditions have a significant impact on quantity and quality of barley (Hordeum vulgare L.) production in most regions of the world. Objective of this study was to determine the relationships between photosynthetic performance index $\left(\mathrm{PI}_{\mathrm{ABS}}\right)$, water use $(\mathrm{WU})$, grain yield-based water use efficiency $\left(\mathrm{WUE}_{\mathrm{G}}\right)$, and grain yield per pot (GYP) of winter barley cultivars grown in a pot trial under short-term drought stress conditions and grain yield and its stability from the multi-environmental field trials. Ten winter barley cultivars were examined in two water treatments. One treatment was well watered, while the second treatment was subjected to short-term stress caused by deficiency of water in the stages of full tillering, beginning of heading, and grain filling. $\mathrm{PI}_{\mathrm{ABS}}$ was measured at full tillering stage while WU, WUE $E_{\mathrm{G}}$, and GYP of barley cultivars were estimated after the whole vegetative cycle. Also, multi-environmental field trials with the same winter barley cultivars were carried out during 4 yr (2004-2007) and 3 yr (2009-2011) with two sowing densities (300 and 450 seeds $\mathrm{m}^{-2}$ ) on multiple locations in the lowland part of the Republic of Croatia. ANOVA showed highly significant $(\mathrm{P} \leq 0.001)$ cultivar effect for all of the examined traits in the pot trial. $\mathrm{PI}_{\mathrm{ABS}}$ of cultivars in both treatments was in a negative nonsignificant correlation with grain yield and grain yield stability (ecovalence) of the same cultivars in multi-environmental field trials. Winter barley cultivars with higher WU and $\mathrm{WUE}_{\mathrm{G}}$ also had higher values of grain yield, and harvest index observed on the basis of the pot trial. WU, WUE $\mathrm{G}_{\mathrm{G}}$, and GYP of 10 barley cultivars in pot trial showed highly positive phenotypic correlation with grain yield of all eight and 10 barley cultivars in the multi-environmental field trials. These results suggests that $\mathrm{WU}$ and $\mathrm{WUE}_{\mathrm{G}}$ could be good indicators for preliminary selection of modern, high yielding, and stable winter barley genotypes which have better water management capabilities.

Key words: Grain yield, Hordeum vulgare, multi-environmental trials, photosynthetic performance index, water use, water use efficiency.

\section{INTRODUCTION}

Different cultivars of winter barley (Hordeum vulgare L.) show various genetic tolerances when they are exposed to different stress conditions. The response of a genotype to different stress conditions has a substantial impact on genotype's stability. Consequently, it is useful to apply different indices that can be calculated from values of a trait, most often yield, observed under stress and nonstress conditions (Talebi et al., 2009; Ilker et al., 2011; Kovacevic et al., 2011). Therefore, investigations of interaction among genotypes (cultivars) and environments give useful information concerning yield and yield

\footnotetext{
${ }^{1}$ Agricultural Institute Osijek, Južno predgrađe 17, Osijek, Croatia *Corresponding author (ana.josipovic@poljinos.hr)

${ }^{2}$ Josip Juraj Strossmayer University of Osijek, Faculty of Agriculture, Kralja Petra Svačića 1d, Osijek, Croatia.

${ }^{3}$ Josip Juraj Strossmayer University of Osijek, Department of Biology, Cara Hadrijana 8/A, Osijek, Croatia.

Received: 12 November 2014.

Accepted: 13 April 2015.
}

doi:10.4067/S0718-58392015000400002 stability (Ceccarelli et al., 2000; Lalic et al., 2009; Mohammadi et al., 2012; Altay, 2012).

Abiotic stress caused by water-limited conditions is very frequently followed by abiotic stress caused by high temperatures. Repetitive heat and drought-stress conditions have a significant impact on quantity and quality of barley production in most regions of the world. Photosynthetic performance index could be a good indicator of drought tolerance in barley cultivars (Oukarroum et al., 2007). Also, rational water use of plant cultivars could be a good indicator for plant production in water-limited conditions (Reynolds et al., 2007; Araus et al., 2008; Blum, 2009; Yong'an et al., 2010). In breeding for drought resistance, indispensable elements of agronomy are production of biomass and water use efficiency (WUE) (Blum, 1993). Several authors have studied the relationship between WUE and various agronomic traits, and they pointed out high positive correlation coefficients for WUE with grain yield and harvest index (Yong'an et al., 2010; Shamsi et al., 2010).

The purpose of this study was estimating the relationships among characteristics of winter barley 
cultivars measured in a pot trial (photosynthetic performance index, water use, grain yield-based water use efficiency, grain yield per pot) and agronomic characters that were estimated in multi-environmental field trials (grain yield and stability of grain yield). These results could be useful for developing breeding methods for preliminary selection of barley genotypes.

\section{MATERIALS AND METHODS}

\section{Plant materials}

One year (2008) trial with 10 winter barley cultivars (A) was grown in vegetative pots according to randomized complete block design with three replicates. Seven winter barley cultivars were developed at the Agricultural Institute Osijek $\left(45^{\circ} 32^{\prime} \mathrm{N}, 18^{\circ} 44^{\prime} \mathrm{E}\right)$, Osijek, Croatia. Five of them were two-rowed: 'Barun' (A11), 'Bingo' (A12), 'Zlatko' (A13), 'Rex' (A15), and 'Bravo' (A17) while 'Lord' (A18) and 'Titan' (A20) were six-rowed cultivars. Two-rowed barley cultivars ('A14' and 'A16') and six-rowed cultivar ('A19') were developed in other institutions.

Eight out of 10 mentioned winter barley cultivars (without new cultivars 'A17' and 'A20') were tested in the multi-environmental field trials from 2004 to 2007 (4 $\mathrm{yr}$; four locations; two sowing densities; three replicates) (Lalic et al., 2009). In addition, every barley cultivar examined in the pot trial (10 cultivars) was tested in the multi-environmental field trials from 2009 to 2011 (3 yr; five locations; two sowing densities, three replicates) (Lalic et al., 2009; 2012).

The vegetative pots were filled with the upper layer (depth up to $30 \mathrm{~cm}$ ) of soil from experimental field of the Agricultural Institute Osijek, Croatia. The soil had good fertility and same mechanical, physical, and chemical composition in every pot. The soil type was Humofluvisol chernozemic, moderately deep gleic, non-calcareous, silty-clay-loam (FAO, 2006). Pore volume was 49\%, water holding capacity $39 \%$, and air capacity $10 \%$ (Romic et al., 2005). Pots were filled with soil, saturated with water up to $39 \%$ of soil volume or $100 \%$ field capacity (FC), and weighed. Mass of each saturated pot was then used as a base for calculating water status in the pots. Pots had drainage holes and trays at the bottom for possible water surplus, which was measured and saved for next watering. The pot dimension was $22.5 \mathrm{~cm}$ in height, 30 $\mathrm{cm}$ in diameter, and $12000 \mathrm{~cm}^{3}$ in volume. Soil volume was $9800 \mathrm{~cm}^{3}$ per pot, and it was measured $10 \mathrm{~d}$ after filling and saturation of the soil with water. Sowing was conducted $7 \mathrm{~d}$ after filling and saturation of the soil with water on 27 December 2008 by planting 32 seeds per vegetative pot. Seeds were arranged in a circle of $20 \mathrm{~cm}$ in diameter, in 16 hills (two seeds per hill) with distance of $3.9 \mathrm{~cm}$ between hills, and at a depth of $3.5 \mathrm{~cm}$. Sowing density in pot experiment was calculated to match field sowing density of 450 seeds $\mathrm{m}^{-2}$ and number of tillers per pot in both treatments ranged from 28.7 to 43.3 with average value of 35.4 tillers per pot.

\section{Growth environment and water stress treatments}

Winter barley cultivars ('A11-A20') were studied in two irrigation (B) treatments: well watered as control (B1) and short-term drought stress conditions (B2). Soil water content was calculated as the difference between water content at $100 \%$ FC (39\% soil volume) and soil water depletion in each vegetative pot and both irrigation treatments. Monitoring the rate of soil water depletion was done by the gravimetric method and with the help of soil moisture sensor (Watermark 30-KTCD-NL, Irrometer Company, Riverside, California, USA). Watermark sensor is hand held device designed for reading Watermark sensors in the field. Sensors were buried at $15 \mathrm{~cm}$ depth in the pots. The readings ranged from $0-199 \mathrm{kPa}$ where 0 stands for wet soil (100\% FC) while $199 \mathrm{kPa}$ stands for dry soil. Soil water measurements were made every day.

The measurements of chlorophyll $a$ fluorescence were conducted as follows: At the end of tillering stage (EC 29-Eucarpia Code, Reiner et al., 1992). From 7 to 12 March 2008 the soil water content in pots was maintained at $30.4 \%$ to $38.4 \%$ of the soil volume $(77.9 \%$ to $98.5 \%$ FC) for B1 and from $21.3 \%$ to $28.7 \%$ of soil volume $(54.6 \%$ to $73.6 \% \mathrm{FC}$ ) for B2 (Figure 1A). During the same period temperatures varied from $8{ }^{\circ} \mathrm{C}$ (early in the morning) to $26{ }^{\circ} \mathrm{C}$ (maximum daily temperature) and $80 \%$ to $99 \% \mathrm{RH}$. On the 12 March (day photosynthetic parameters were measured) minimum water content in the pots varied from $20.7 \%$ to $21.8 \%$ of the soil volume ( $53 \%$ to $56 \%$ FC) for the stressful treatment (B2), and from $37.4 \%$ to $38.6 \%$ of the soil volume ( $96 \%$ to $99 \%$ FC) for the control (B1).

During flag leaf stage and the beginning of heading stage (EC 49/51), from 20 to 25 April 2008, soil water content in pots was maintained at $27.2 \%$ to $35.5 \%(69.7 \%$ to $91.0 \%$ FC) of the soil volume for B1 and from $16.4 \%$ to $20.0 \%$ of the soil volume $(42.1 \%$ to $51.3 \% \mathrm{FC})$ for B2 (Figure 1B). During the same period temperatures varied from $3.7^{\circ} \mathrm{C}$ (minimum night temperature) to 21.6 ${ }^{\circ} \mathrm{C}$ (maximum daily temperature) and $30 \%$ to $99 \% \mathrm{RH}$. On 25 April minimum water content in pots varied from $15.2 \%$ to $17.9 \%$ of the soil volume (39\% to $46 \%$ FC) for the stressful treatment (B2) and from $25.2 \%$ to $29.3 \%$ of the soil volume ( $65 \%$ to $75 \%$ FC) for B1.

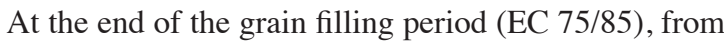
18 to 21 May 2008, the soil moisture content in pots was maintained at $26.1 \%$ to $31.9 \%$ of the soil volume $(66.9 \%$ to $81.8 \% \mathrm{FC}$ ) for $\mathrm{B} 1$ and from $20.8 \%$ to $24.2 \%$ of the soil volume $(53.3 \%$ to $62.1 \%$ FC) for B2 (Figure 1C). During the same period temperature varied from $13.1^{\circ} \mathrm{C}$ (minimum night temperature) to $32.6{ }^{\circ} \mathrm{C}$ (maximum daily temperature) and $\mathrm{RH}$ from $28 \%$ to $99 \%$. On the 21 May the minimum water content in pots varied from $19.9 \%$ to $21 \%$ of soil volume ( $51 \%$ to $56 \% \mathrm{FC}$ ) for $\mathrm{B} 2$, and from $25.4 \%$ to $27.3 \%$ of soil volume $(65 \%$ to $70 \% \mathrm{FC})$ for $\mathrm{B} 1$. 

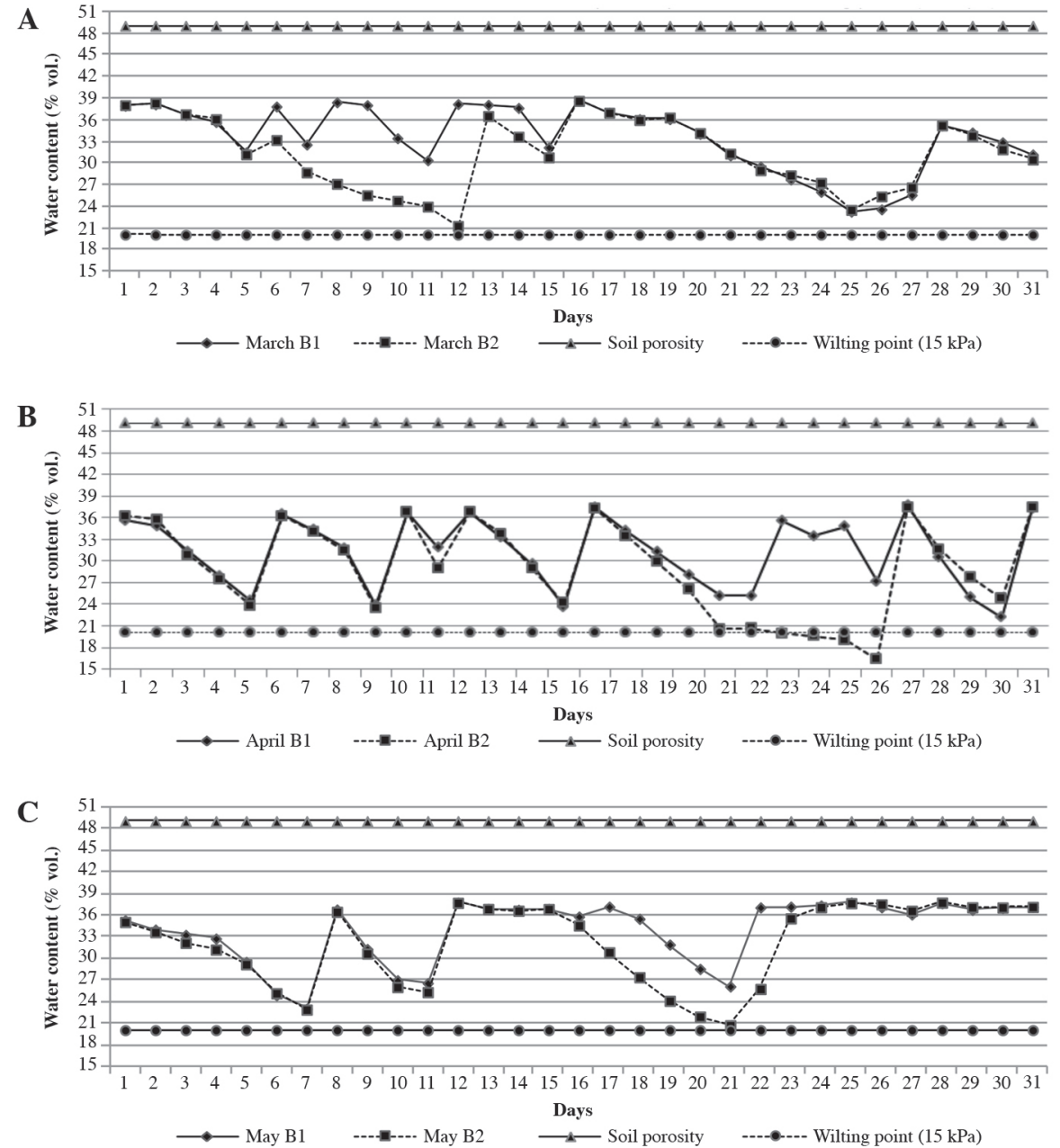

Figure 1. Soil water content in pots at different regimes of soil moisture (B1: control treatment; B2: drought stress treatment). First stress period (A) was from 7 to 12 March at the end of tillering stage, second stress period (B) was from 20 to 25 April in the flag leaf and beginning of heading stage, and third stress period (C) was from 18 to 21 May in grain filling stage.

The experiment was performed in greenhouse in the period from sowing to the beginning of stem elongation stage and after that in the open area near the greenhouse. During the experiment in the greenhouse, temperatures varied from 0.5 to $28{ }^{\circ} \mathrm{C}$ and $\mathrm{RH}$ from $70 \%$ to $99 \%$. In open area temperatures varied from -3.9 to $32.9{ }^{\circ} \mathrm{C}$ and $\mathrm{RH}$ from $25.8 \%$ to $99 \%$. After relocation to the open area, pluviometer was set to measure precipitation. These amounts of rainfall were accounted as a part of water use (WU). From the beginning of stem elongation to the beginning of ear emergence the amount of precipitation was $19.3 \mathrm{~mm} \mathrm{~m}^{-2}\left(1.33 \mathrm{~L} \mathrm{pot}^{-1}\right)$ and from ear emergence to full maturity was $65.1 \mathrm{~mm} \mathrm{~m}^{-2}\left(4.5 \mathrm{~L} \mathrm{pot}^{-1}\right)$.

\section{Pot trial analysis}

Vegetative pot analysis included photosynthetic performance index $\left(\mathrm{PI}_{\mathrm{ABS}}\right)$, biomass weight per pot (total weight of air-dry plants without root) (BWP), harvest index (HI, ratio between grain weight per pot and biomass weight per pot), water use (WU, total water added for each winter barley cultivar from sowing to maturity), grain yield-based water use efficiency $\left(\mathrm{WUE}_{\mathrm{G}}\right.$ ) (Viets, 1962; Passioura, 1977; Siddique et al., 1990; Boutraa, 2010; Zhang et al., 2010), and grain yield per pot (GYP).

$$
W U E_{G}=G Y P / W U \text {. }
$$

$\mathrm{WUE}_{\mathrm{G}}=\mathrm{g} \mathrm{L}^{-1}$ (gram of grains per liter of water evapotranspiration).

Stability indices (SI) of photosynthetic performance index $\left(\mathrm{PI}_{\mathrm{ABS}}\right)$ of the cultivars were calculated by formulas for yield (Talebi et al., 2009), with reference to other characters (Kovacevic et al., 2013):

$$
\text { SI of } P I_{A B S}=P I_{A B S} B 2 i / P I_{A B S} B 1 i
$$

where $P I_{A B S} B 2 i$ is photosynthetic performance index of the $\mathrm{i}^{\text {th }}$ winter barley cultivar in B2 treatment (drought stress); $i$ is from 1 to $10, P I_{A B S} B 1 i$ is photosynthetic performance index of the $\mathrm{i}^{\text {th }}$ winter barley cultivar in the $\mathrm{B} 1$ treatment (well watered). 
Evapotranspiration (ET) or water use (WU) for winter barley cultivars and treatments in pots was calculated using the soil water balance model according to Doorenbos and Kassam (1979). Since there was no capillary rise, downward drainage or surface runoff in vegetative pots, evapotranspiration was calculated from the following equation:

$$
E T=\Delta W+I+P
$$

where WU is evapotranspiration (ET) from emergence to maturation, $\Delta W$ is the difference in weight between two measurements of soil water content in pots at the time from sowing to maturation $\left(\mathrm{kg} \mathrm{pot}^{-1}\right), I$ is irrigation $(\mathrm{L}$ $\left.\operatorname{pot}^{-1}\right)$, and $P$ is precipitation $\left(\mathrm{L} \mathrm{pot}^{-1}\right)$.

Water use was calculated as addition of water (irrigation and precipitation) in every pot from sowing to maturity and was dependent on barley cultivars and water treatments (B1 and B2). Figure 2 shows water use per cultivar in the different stages of barley growth in B1 and B2 treatments.

Chlorophyll $a$ fluorescence was measured both on control and stressed plants at the end of the tillering stage (EC 29) in the morning hours (07:00-09:00 h). At the time of measurement average soil water content in pots was $38.2 \%$ volume of soil for B1 and $21.3 \%$ for B2 (Figure 1A). Leaves of barley plants were adapted to darkness for 30 min using special plastic clips. The measurement was carried out on the second leaf from the top on three plants per pot by portable fluorimeter (Handy Plant Efficiency Analyser, Handy PEA, Hansatech Instruments, King's Lynn, Norfolk, UK). After the adaptation of leaves to darkness a single one second light pulse $(3500 \mu \mathrm{mol}$ $\left.\mathrm{m}^{-2} \mathrm{~s}^{-1}\right)$ was applied with the help of three light-emitting diodes $(650 \mathrm{~nm})$. The fast fluorescence kinetics $\left(\mathrm{F}_{0}\right.$ to $\left.\mathrm{F}_{\mathrm{M}}\right)$ was recorded during $10 \mu \mathrm{s}$ to $1 \mathrm{~s}$. The measured data were analyzed by the JIP test (Strasser et al., 1995), and used to calculate $\mathrm{PI}_{\mathrm{ABS}}$ (Strasser et al., 2000) as follows:

$$
P I_{A B S}=\frac{1-\left(F_{0} / F_{M}\right)}{M_{0} / V_{j}} \times \frac{\left(F_{M}-F_{0}\right)}{F_{0}} \times \frac{1-V_{j}}{V_{j}}
$$

where $F_{0}$ is fluorescence intensity at $50 \mu \mathrm{s}, F_{M}$ is maximum fluorescence intensity, $M_{0}$ is initial slope of fluorescence kinetics, which is derived from the equation:
$M O=4\left(F 300 \mu s-F_{0}\right) /\left(F_{M}-F_{0}\right), V_{J}$ is relative variable fluorescence at $2 \mathrm{~ms}$ calculated as $V_{J}=\left(F_{J}-F_{0}\right) /\left(F_{M}-F_{0}\right)$, and $F_{J}$ is fluorescence intensity at the $J$ step (at $2 \mathrm{~ms}$ ).

The Wricke's ecovalence $\left(\mathrm{W}_{\mathrm{i}}\right)$ defines the share of each genotype in the sum of squares of the Genotype $\times$ Environment interaction (Bujak et al., 2014). In breeding, $\mathrm{W}_{\mathrm{i}}$ is used as parameter of cultivar stability, and it is a reliable measure for the assessment of individual genotype adaptation to different environmental conditions. It is highly heritable, and in stable cultivars $\mathrm{W}_{\mathrm{i}}$ value is relatively low. Grain yield and ecovalence $\left(\mathrm{W}_{\mathrm{i}}\right)$ measured in the multi-environmental field trials were used in correlation analyses along with variables from the pot trial $\left(\mathrm{PI}_{\mathrm{ABS}}\right.$, SI of $\mathrm{PI}_{\mathrm{ABS}}, \mathrm{BWP}, \mathrm{HI}, \mathrm{WU}, \mathrm{WUE}_{\mathrm{G}}$, and GYP).

\section{Statistical analysis}

ANOVA was carried out and differences between treatments and cultivars were tested by the Duncan's test $(\mathrm{P} \leq 0.05$ and $\mathrm{P} \leq 0.01)$ using SAS 9.1 statistical software (SAS Institute, Cary, North Carolina, USA). Data were also subjected to correlation analysis using Microsoft Office Excel 2010.

\section{RESULTS}

The ANOVA showed that the effect of barley cultivar was highly significant $(\mathrm{P} \leq 0.001)$ for all of the examined traits in the pot trial: $\mathrm{PI}_{\mathrm{ABS}}, \mathrm{GYP}, \mathrm{BWP}, \mathrm{HI}, \mathrm{WU}$ per pot, and $\mathrm{WUE}_{\mathrm{G}}($ Table 1). Differences among treatments were also highly significant $(\mathrm{P} \leq 0.001)$, except for $\mathrm{HI}$ and $\mathrm{WUE}_{\mathrm{G}}$. Interactions between cultivars and treatments were not significant for all of the examined traits (Table 1).

The $\mathrm{PI}_{\mathrm{ABS}}, \mathrm{WU}, \mathrm{WUE}_{\mathrm{G}}, \mathrm{HI}$, and GYP values from the pot trial are shown in Figure 3 and Figure 4a-4d, respectively.

Six-rowed 'A18' had the highest value of $\mathrm{PI}_{\mathrm{ABS}}$, while two-rowed 'A12' had the lowest value of $\mathrm{PI}_{\mathrm{ABS}}$. Also, values of $\mathrm{PI}_{\mathrm{ABS}}$ showed that there was no difference between treatments for each cultivar separately, except for 'A18' (Figure 3).

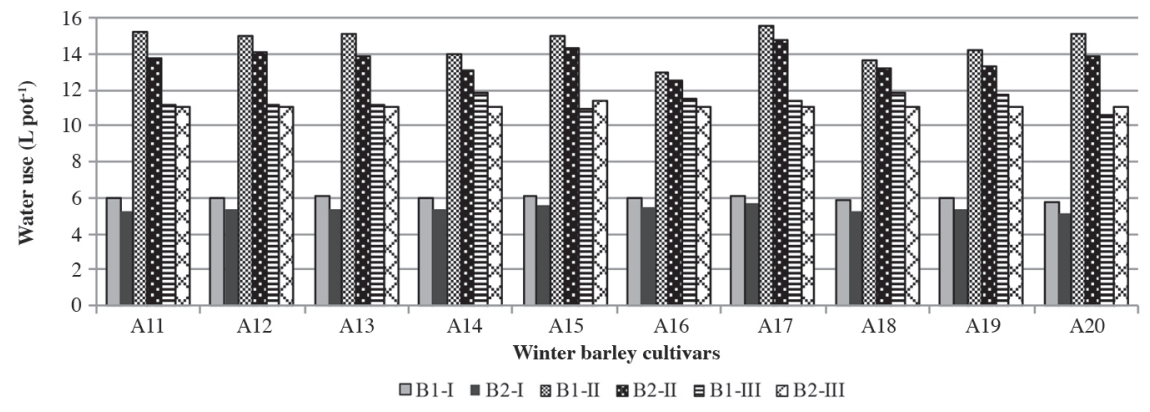

Figure 2. Quantity of water use for ten winter barley cultivars in the growth period from sowing to the end of tillering (B1-I; B2-I), end of tillering to beginning of heading stage (B1-II; B2-II), and beginning of heading to maturation stage (B1-III; B2-III) for well watered treatment (B1) and short term drought stress treatment (B2). 
Table 1. The variance and F-test for photosynthetic performance index $\left(\mathbf{P I}_{\mathrm{ABS}}\right)$, harvest index $(\mathrm{HI})$, water use (WU), grain yield based water use efficiency $\left(W_{\mathrm{G}}\right)$, biomass weight per pot (BWP), and grain yield per pot (GYP) of winter barley cultivars, treatments, and interaction in the trial under control (B1) and in short-term drought stress conditions (B2).

\begin{tabular}{llcccc}
\hline Variance & \multicolumn{5}{c}{ Mean square (MS) } \\
\hline $\begin{array}{l}\text { Source of } \\
\text { variability }\end{array}$ & Replicate & Cultivar & Treatment & Interaction & Error \\
\hline $\begin{array}{l}\text { Degrees of } \\
\text { freedom (df) }\end{array}$ & \multicolumn{1}{c}{2} & 9 & 1 & 9 & 38 \\
\hline PI $_{\text {ABS }}$ & $0.11443 *$ & $0.11249 * * *$ & $0.26075 * *$ & 0.01911 & $0.02933^{+}$ \\
HI & 0.000783 & $0.011923 * * *$ & 0.000002 & 0.000904 & 0.000890 \\
WU & 0.1968 & $14.0136^{* * *}$ & $45.917 * * *$ & 0.3347 & 0.2120 \\
WUE & 0.00804 & $0.07466 * * *$ & 0.00405 & 0.005407 & 0.00603 \\
BWP & 4.183 & $377.100 * * *$ & $504.252 * * *$ & 16.971 & 14.004 \\
GYP & 5.454 & $92.495 * * *$ & $94.224 * * *$ & 5.111 & 5.878 \\
\hline
\end{tabular}

$*$, **, *** Significant at the $0.05,0.01$, and 0.001 probability levels, respectively.

${ }^{+}$Error of photosynthetic performance index $\left(\mathrm{PI}_{\mathrm{ABS}}\right)$ has 158 degrees of freedom because there were three measurements per pot.

$\mathrm{HI}$ : harvest index, WU: water use, $\mathrm{WUE}_{\mathrm{G}}$ : grain yield-based water use efficiency, BWP: biomass weight per pot, GYP: grain yield per pot.

Two-rowed 'A17' and 'A15' had the highest values of WU per pot while six-rowed 'A18' and two-rowed 'A16' had the lowest WU values (Figure 4a). Two-rowed 'A13' had the highest $\mathrm{WUE}_{\mathrm{G}}$, which was highly significant in relation to other barley cultivars, in the pot trial, while two-rowed 'A16' had the lowest $\mathrm{WUE}_{\mathrm{G}}$ (Figure 4b). Six-rowed 'A20' and two-rowed 'A11' had the highest HI while two-rowed 'A17' and 'A16' had the lowest HI (Figure 4c).

Grain yield per pot ranged similarly to $\mathrm{WUE}_{\mathrm{G}}$ (Figures $4 \mathrm{~b}$ and $4 \mathrm{~d})$. The argument for this assessment was a strong positive phenotypic correlation between $\mathrm{WUE}_{\mathrm{G}}$ and GYP $(\mathrm{r}=0.867$ to 0.992$)$ for B1 and B2 treatments (Table 2).

The difference of WU between $\mathrm{B} 1$ and $\mathrm{B} 2$ treatments for each cultivar was highly significant $(\mathrm{P} \leq 0.01)$, except for two-rowed 'A15' (Figure 4a). Highly significant GYP differences between treatments were estimated for sixrowed 'A19' (Figure 4d).

There were no significant phenotypic correlation coefficients of $\mathrm{PI}_{\mathrm{ABS}}$ with $\mathrm{BWP}, \mathrm{HI}$ and GYP for both treatments (Table 2). However, there was a tendency of positive phenotypic correlations between SI of $\mathrm{PI}_{\mathrm{ABS}}$ and $\mathrm{HI}$ (from 0.411 to 0.584 ), as well as between SI of $\mathrm{PI}_{\mathrm{ABS}}$ and GYP (from 0.284 to 0.465 ) (Table 2). Positive phenotypic correlation coefficients were estimated for WU and biomass weight per pot (BWP) ( $\mathrm{r}=0.530$ to 0.747 ) in both treatments (B1 and B2). Also, positive phenotypic correlation was estimated between WU and GYP ( $\mathrm{r}=$ 0.559 to 0.817 ) (Table 2). $\mathrm{WUE}_{\mathrm{G}}$ in both treatments was positively correlated with BWP ( $\mathrm{r}=0.317$ to 0.621$)$, HI ( $\mathrm{r}$ $=0.361$ to 0.708$)$, and GYP $(r=0.867$ to 0.992$)$ (Table 2$)$.

Winter barley cultivars examined in the pot trial were also examined in multi-environmental field trials in the lowland part of the Republic of Croatia during 4 yr (20042007, eight cultivars, four locations) and 3 yr (20092011, 10 cultivars, five locations) in two sowing densities (300 and 450 seeds $\mathrm{m}^{-2}$ ) (Lalic et al., 2009; 2012). The parameters of winter barley cultivars from the pot trial were correlated with the average grain yield and $\mathrm{W}_{\mathrm{i}}$ of the same cultivars in the multi-environmental field trials (Table 3). Positive phenotypic correlation coefficients were estimated among WU of barley cultivars in the pot trial for B1 and B2 treatments and average grain yield of cultivars in the multi-environmental field trial with eight cultivars (treatment $\mathrm{B} 1: \mathrm{r}=0.925$; treatment $\mathrm{B} 2: \mathrm{r}=0.786$ ) and 10 cultivars (treatment $\mathrm{B} 1: \mathrm{r}=0.761$; treatment $\mathrm{B} 2 \mathrm{:} \mathrm{r}$ $=0.825)$ (Table 3$)$. Also, there was a tendency that winter barley cultivars with higher values of WU had better $\mathrm{W}_{\mathrm{i}}(\mathrm{r}$ $=0.405$ to 0.709 ) (Table 3 ).

Similarly, $\mathrm{WUE}_{\mathrm{G}}$ of eight barley cultivars in both water treatments of the pot trial was mostly in a high positive correlation with grain yield of the same cultivars in the multi-environmental field trial (treatment $\mathrm{B} 1: \mathrm{r}=0.782$; treatment $\mathrm{B} 2: \mathrm{r}=0.823$ ). Also, there was a tendency of positive correlations of $\mathrm{WUE}_{\mathrm{G}}$ with grain yield stability $\left(\mathrm{W}_{\mathrm{i}}\right)(\mathrm{r}=0.357$ and 0.524 for $\mathrm{B} 1$ and $\mathrm{B} 2$ treatments respectively) (Table 3). No significant positive correlation coefficient for $\mathrm{WUE}_{\mathrm{G}}$ and grain yield was found in the multi-environmental trial with 10 winter barley cultivars $(\mathrm{r}=0.486$ and 0.348 for $\mathrm{B} 1$ and $\mathrm{B} 2$ treatments respectively) (Table 3). However, there was also a

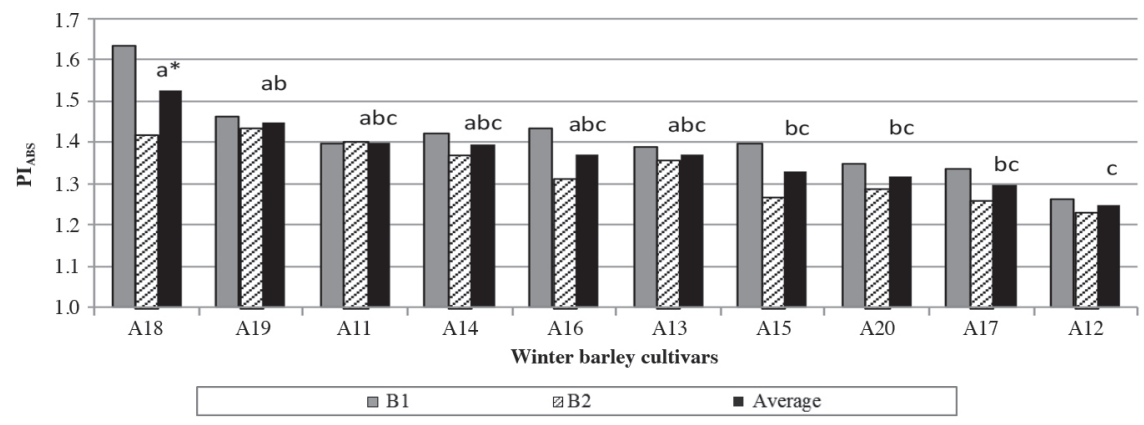

Differences between B1 and B2 treatments are calculated for each cultivar separately.

*Only cultivar A18 had significant difference $(\mathrm{P} \leq 0.01)$. Means with the same letter are not significantly different according to Duncan's test ( $\leq 0.01)$.

Figure 3. Relative values of the photosynthetic performance index $\left(\mathrm{PI}_{\mathrm{ABS}}\right)$ in the well watered treatment $(\mathrm{B} 1)$, short term drought stress treatment (B2), and average of treatments for ten winter barley cultivars in pot experiment. 

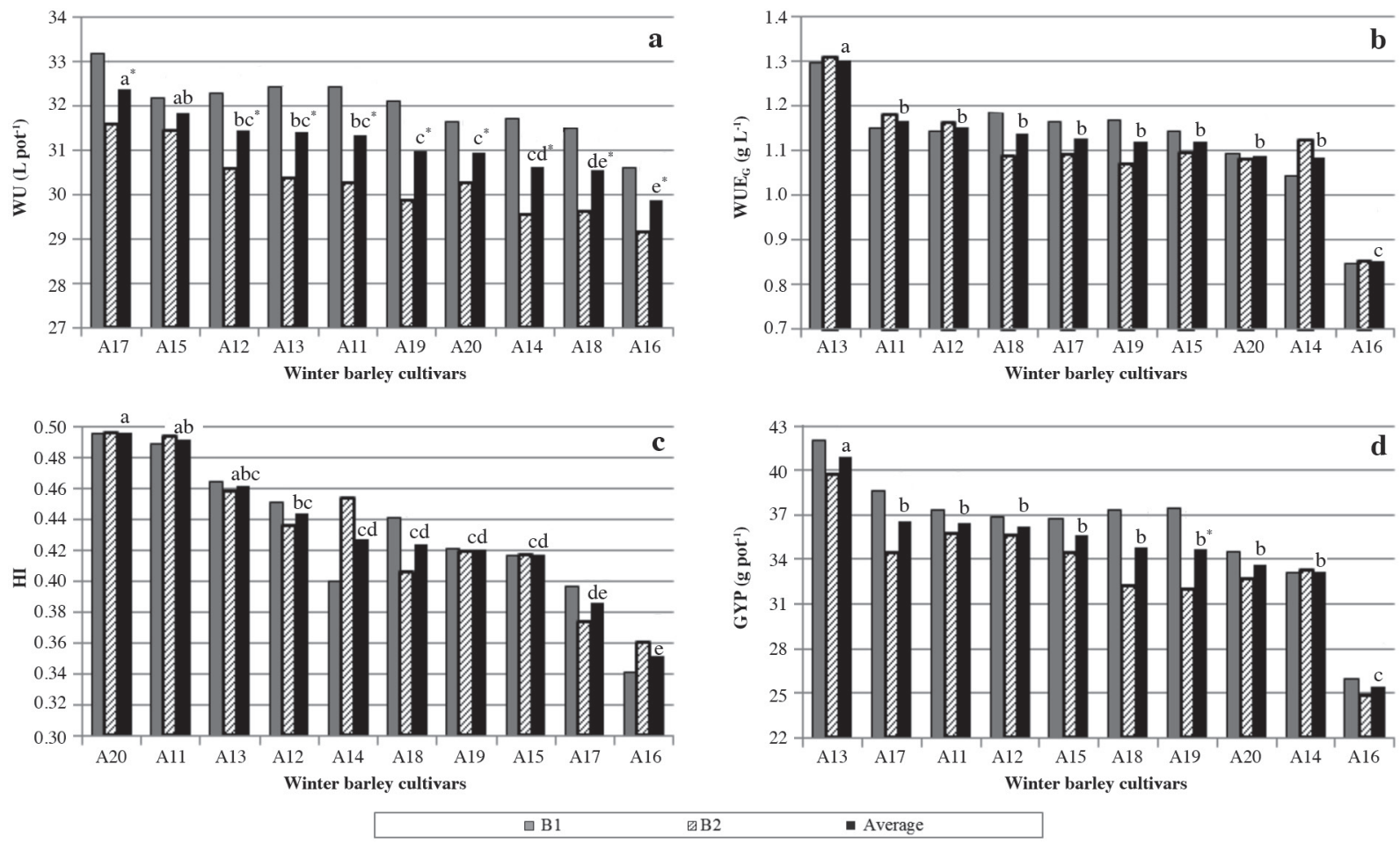

Duncan's test: Average value means with the same letter are not significantly different $(\mathrm{P} \leq 0.01)$.

*Differences between B1 and B2 treatment are significant for each cultivar separately $(\mathrm{P} \leq 0.01)$.

Figure 4. The average values of ten winter barley cultivars for: water use (WU) (a), grain yield-based water use efficiency (WUE ${ }_{G}$ ) (b), harvest index (HI) (c), and grain yield per pot (GYP) (d) in control treatment (B1) and short-term drought stress treatment (B2).

tendency of positive phenotypic correlations between $\mathrm{WUE}_{\mathrm{G}}$ and grain yield stability $\left(\mathrm{W}_{\mathrm{i}}\right)(\mathrm{r}=0.358$ and 0.697 for B1 and B2 treatments respectively) (Table 3). High significant correlation coefficients also appeared between grain yield per pot (GYP) and eight barley cultivars in the multi-environmental field trial in a similar way as $\mathrm{WUE}_{\mathrm{G}}$ (Table 3).

Average grain yield and $\mathrm{W}_{\mathrm{i}}$ of the multi-environmental field trials for eight and ten winter barley cultivars in two sowing densities (300 and 450 seeds $\mathrm{m}^{-2}$ ) are presented in Table 4. Sowing densities of multi-environmental field trials (300 and 450 seed $\mathrm{m}^{-2}$ ) did not have a significant impact on all estimated correlation coefficients (Table 3) nor the grain yield (Table 4).

\section{DISCUSSION}

Results of this paper coincide with examination of Akhter et al. (2008) and Shamsi et al. (2010). They pointed out higher positive correlation coefficients between $\mathrm{WUE}_{\mathrm{G}}$ and grain yield of wheat cultivars. Blum (2005; 2009) suggested that high water use efficiency of plant genotypes could reduce transpiration and water use, which could be crucial for plant production and reduction of yield. These statements are confirmed in the results of this study because WU of the examined barley cultivars was also positively correlated with GYP (Table 2). Furthermore, WU had a significant correlation with grain yield of eight and ten barley cultivars in the multi-environmental field

Table 2. Phenotypic correlation coefficients for photosynthetic performance index (PI $\left.{ }_{\mathrm{ABS}}\right)$, $\mathrm{stability}_{\text {index of }} \mathrm{PI}_{\mathrm{ABS}}\left(\mathrm{SI}\right.$ of $\left.\mathbf{P I} \mathrm{ABS}_{\mathrm{ABS}}\right)$, water use (WU), and grain yield-based water use efficiency $\left(\mathrm{WUE}_{\mathrm{G}}\right)$ of different winter barley cultivars, with biomass weight per pot, harvest index, and grain yield per pot of cultivars in control treatment (B1), short-term drought stress treatment (B2), and average of treatments.

\begin{tabular}{|c|c|c|c|c|c|c|c|c|c|}
\hline \multirow{2}{*}{$\begin{array}{l}\text { Correlated } \\
\text { variables } \\
\end{array}$} & \multicolumn{3}{|c|}{ Biomass weight per pot } & \multicolumn{3}{|c|}{ Harvest index } & \multicolumn{3}{|c|}{ Grain yield per pot } \\
\hline & B1 & B2 & Average & B1 & B2 & Average & B1 & $\mathrm{B} 2$ & Average \\
\hline $\mathrm{PI}_{\mathrm{ABS}}-\mathrm{B} 1$ & 0.043 & -0.153 & -0.058 & -0.155 & -0.232 & -0.198 & -0.077 & -0.327 & -0.199 \\
\hline $\mathrm{PI}_{\mathrm{ABS}}-\mathrm{B} 2$ & -0.004 & -0.256 & -0.134 & 0.123 & 0.186 & 0.159 & 0.123 & -0.038 & 0.048 \\
\hline SI of $\mathrm{PI}_{\mathrm{ABS}}$ & -0.077 & -0.067 & -0.073 & 0.411 & 0.584 & 0.511 & 0.284 & 0.465 & 0.379 \\
\hline WU-B1 & 0.647 & 0.731 & 0.705 & 0.361 & 0.185 & 0.287 & 0.803 & 0.789 & 0.817 \\
\hline WU-B2 & 0.530 & 0.686 & 0.622 & 0.212 & -0.017 & 0.107 & 0.574 & 0.559 & 0.581 \\
\hline $\mathrm{WUE}_{\mathrm{G}}-\mathrm{B} 1$ & 0.536 & 0.621 & 0.592 & 0.657 & 0.361 & 0.535 & 0.992 & 0.881 & 0.964 \\
\hline $\mathrm{WUE}_{\mathrm{G}}-\mathrm{B} 2$ & 0.317 & 0.460 & 0.398 & 0.708 & 0.617 & 0.688 & 0.867 & 0.978 & 0.943 \\
\hline
\end{tabular}

$\mathrm{r} \geq 0.632 \mathrm{P} \leq 0.05 ; \mathrm{r} \geq 0.765 \mathrm{P} \leq 0.01 ; \mathrm{r} \geq 0.872 \mathrm{P} \leq 0.001$. 
Table 3. Phenotypic correlation coefficients of $\mathbf{P I} \mathbf{I}_{\mathrm{ABS}}$, Wricke's ecovalence $\left(W_{i}\right)$, stability index $(S I)$ of $P I_{A B S}$, water use (WU), grain yield-based water use efficiency $\left(W_{U} E_{G}\right)$, and grain yield per pot (GYP) of 10 winter barley cultivars tested in pot trial (B1: control treatment; B2: drought stress treatment) with average grain yield of the same winter barley cultivars from multi-environmental field trials with two sowing densities ( 350 and 450 seeds $\mathrm{m}^{-2}$ ).

\begin{tabular}{|c|c|c|c|c|c|c|c|c|}
\hline \multirow{3}{*}{$\begin{array}{l}\text { Parameters } \\
\text { on the basis } \\
\text { of pot trial }\end{array}$} & \multicolumn{4}{|c|}{ Trial with eight cultivars } & \multicolumn{4}{|c|}{ Trial with ten cultivars } \\
\hline & \multicolumn{2}{|c|}{$\begin{array}{c}\text { Sowing } \\
\text { density } \\
\left(\text { seeds } \mathrm{m}^{-2} \text { ) }\right.\end{array}$} & \multirow[b]{2}{*}{ Average } & \multirow[b]{2}{*}{$W_{i}$} & \multicolumn{2}{|c|}{$\begin{array}{c}\text { Sowing } \\
\text { density } \\
\left(\text { seeds } \mathrm{m}^{-2}\right)\end{array}$} & \multirow[b]{2}{*}{ Average } & \multirow[b]{2}{*}{$\mathrm{W}_{\mathrm{i}}$} \\
\hline & 300 & 450 & & & 300 & 450 & & \\
\hline $\mathrm{PI}_{\mathrm{ABS}}-\mathrm{B} 1$ & -0.458 & -0.458 & -0.459 & -0.357 & -0.433 & -0.675 & -0.568 & -0.600 \\
\hline $\mathrm{PI}_{\mathrm{ABS}}-\mathrm{B} 2$ & -0.205 & -0.205 & -0.207 & -0.167 & -0.425 & -0.541 & -0.494 & -0.358 \\
\hline SI of $\mathrm{PI}_{\mathrm{ABS}}$ & 0.454 & 0.450 & 0.451 & -0.262 & 0.155 & 0.366 & 0.269 & 0.370 \\
\hline WU-B1 & 0.922 & 0.926 & 0.925 & 0.405 & 0.720 & 0.773 & 0.761 & 0.709 \\
\hline WU-B2 & 0.775 & 0.792 & 0.786 & 0.500 & 0.791 & 0.828 & 0.825 & 0.685 \\
\hline $\mathrm{WUE}_{\mathrm{G}}-\mathrm{B} 1$ & 0.776 & 0.791 & 0.782 & 0.357 & 0.506 & 0.447 & 0.486 & 0.358 \\
\hline $\mathrm{WUE}_{\mathrm{G}}-\mathrm{B} 2$ & 0.808 & 0.839 & 0.823 & 0.524 & 0.307 & 0.370 & 0.348 & 0.697 \\
\hline GYP-B1 & 0.812 & 0.827 & 0.819 & 0.228 & 0.568 & 0.529 & 0.559 & 0.419 \\
\hline GYP-B2 & 0.865 & 0.896 & 0.881 & 0.571 & 0.451 & 0.519 & 0.497 & 0.830 \\
\hline
\end{tabular}

$\mathrm{r} \geq 0.707 \mathrm{P} \leq 0.05 ; \mathrm{r} \geq 0.834 \mathrm{P} \leq 0.01 ; \mathrm{r} \geq 0.925 \mathrm{P} \leq 0.001$ for trial with eight cultivars

$r \geq 0.632 \mathrm{P} \leq 0.05 ; \mathrm{r} \geq 0.765 \mathrm{P} \leq 0.01 ; \mathrm{r} \geq 0.872 \mathrm{P} \leq 0.001$ for trial with ten cultivars.

trials (Table 3). These results suggest that high correlation of WU and $\mathrm{WUE}_{\mathrm{G}}$ with GYP of barley cultivars can be used as a selection criterion for breeding on drought tolerance. High WU can also be characteristic of drought intolerant genotypes if measured in strong long-term drought conditions. In addition, $\mathrm{WUE}_{\mathrm{G}}$ could be a good indicator of rational WU by different winter barley cultivars.

Likewise, the results of this study also demonstrated that high $\mathrm{WUE}_{\mathrm{G}}$ is a characteristic of high yielding winter barley cultivars like two-rowed winter barley 'A11', 'A12', and 'A13'. However, winter barley 'A17', which had the highest grain yield in the multi-environmental trials (Table 4), had the highest WU values (Figure 4a), while $\mathrm{WUE}_{\mathrm{G}}$ was at the level of average values of all cultivars in the trial (Figure 4b). Results of this study also confirm that higher WU is a characteristic of high yielding winter barley cultivars. This characteristic of barley cultivars could be an indicator for better absorption of nutritive elements and water from soil, which is important for all physiological processes. Stomatal conductance causes leaf cooling through transpiration and thus has important impact in plant's heat stress tolerance (Reynolds et al., 1994; Vilhelmsen et al., 2001; Tuberosa, 2012; Siddiqui et al., 2014). Consequently, results of Radin et al. (1988) and Bernacchi et al. (2006; 2007) confirmed interdependence of transpiration and drought tolerance with positive correlations of WU with stomatal conductance and photosynthetic rate.

Photosynthetic performance index can be very suitable and sensitive parameter to investigate plant's overall photosynthetic efficiency under different abiotic stresses (Appenroth et al., 2001), but many authors confirm that plant's first reaction to drought stress is increase in photosynthetic efficiency parameters and thus performance index as well (Shao et al., 2005; Huseynova et al., 2010; Balouchi, 2010; Kovacevic et al., 2013).

This reaction is linked to defensive response of plant's photosynthetic apparatus on mild and moderate drought stress conditions that accurs in early stages of growth (Shao et al., 2008; Liu et al., 2010).

Negative correlations of $\mathrm{PI}_{\mathrm{ABS}}$ with yield parameters indicate that barley cultivars tested in pot trial were subjected only to mild short-term drought stress conditions which did not have significant impact on photosynthetic efficiency of barley cultivars. However, stability index of $\mathrm{PI}_{\mathrm{ABS}}$ (relation between $\mathrm{PI}_{\mathrm{ABS}}$ of stressful and $\mathrm{PI}_{\mathrm{ABS}}$ of well watered treatment for each cultivar) was in low positive correlation with grain yield of cultivars in pot trial and in both multi-environmental trials (Tables 2 and 3). Similar, but more expressed connections were estimated for winter wheat cultivars (Kovacevic et al., 2013). Inostroza et al. (2015) reported the low correlation between single physiological traits and DM production under drought conditions for 100 Lotus tenuis genotypes, but the combination of physiological traits in multi-physiological indices may be effective for selection of drought-tolerant genotypes.

Hejnák et al. (2011) suggest the use of photosynthesis and transpiration ratio as water use efficiency (WUE) for determination of water management capabilities of individual spring barley genotypes, especially under stress

Table 4. Average grain yield and Wricke's ecovalence $\left(W_{i}\right)$ of the multi-environmental field trials for eight (2004-2007) and ten (2009-2011) winter barley cultivars in two sowing densities ( 300 and 450 seeds $\mathbf{~ m}^{-2}$ ).

\begin{tabular}{|c|c|c|c|c|c|c|c|c|}
\hline \multirow[b]{2}{*}{ Cultivars } & \multicolumn{4}{|c|}{$\begin{array}{c}\text { Grain yield 2004-2007 ( } \mathrm{t} \mathrm{ha}^{-1} \text { ) for different sowing } \\
\text { densities (seeds } \mathrm{m}^{-2} \text { ) }\end{array}$} & \multicolumn{4}{|c|}{$\begin{array}{c}\left.\text { Grain yield 2009-2011 ( } \mathrm{t} \mathrm{ha}^{-1}\right) \text { for different sowing } \\
\left.\text { densities (seeds } \mathrm{m}^{-2}\right)\end{array}$} \\
\hline & 300 & 450 & Average & $\mathrm{W}_{\mathrm{i}}$ & 300 & 450 & Average & $\mathrm{W}_{\mathrm{i}}$ \\
\hline A 12 & $7.410 \mathrm{a}$ & $7.310 \mathrm{a}$ & $7.360 \mathrm{a}$ & 9.88 & $6.532 b$ & $6.707 \mathrm{~b}$ & $6.620 \mathrm{~b}$ & 1.68 \\
\hline A11 & 7.330ab & $7.340 \mathrm{a}$ & $7.335 \mathrm{a}$ & 7.69 & $6.544 b$ & $6.654 b$ & $6.599 \mathrm{~b}$ & 1.16 \\
\hline A13 & $7.140 \mathrm{ab}$ & $7.290 \mathrm{a}$ & $7.215 \mathrm{ab}$ & 4.72 & $6.368 b$ & $6.687 b$ & $6.527 b$ & 2.77 \\
\hline A 15 & $7.030 \mathrm{~b}$ & $7.080 \mathrm{a}$ & $7.055 \mathrm{~b}$ & 4.47 & $6.372 b$ & $6.512 b c$ & $6.442 \mathrm{bc}$ & 2.88 \\
\hline A19 & $6.550 \mathrm{c}$ & $6.480 \mathrm{~b}$ & $6.505 \mathrm{c}$ & 16.41 & $6.216 b c$ & $6.255 \mathrm{~cd}$ & $6.236 \mathrm{~cd}$ & 9.42 \\
\hline A 18 & $6.540 \mathrm{c}$ & $6.460 \mathrm{~b}$ & $6.510 \mathrm{c}$ & 7.81 & $6.227 b c$ & $5.836 \mathrm{e}$ & $6.055 \mathrm{de}$ & 4.35 \\
\hline A 16 & $5.570 \mathrm{e}$ & $5.550 \mathrm{c}$ & $5.560 \mathrm{e}$ & 38.49 & $5.911 \mathrm{~cd}$ & $5.954 \mathrm{de}$ & $5.933 \mathrm{e}$ & 10.81 \\
\hline A14 & $6.210 \mathrm{~d}$ & $6.190 \mathrm{~b}$ & $6.200 \mathrm{~d}$ & 6.55 & $5.643 d$ & $5.713 \mathrm{e}$ & $5.678 \mathrm{f}$ & 16.48 \\
\hline A17 & & & & & $7.059 \mathrm{a}$ & $7.366 a$ & 7.213a & 3.40 \\
\hline A 20 & & & & & $6.477 \mathrm{~b}$ & $6.631 \mathrm{~b}$ & $6.554 b$ & 3.42 \\
\hline
\end{tabular}

Duncan's test. Means with the same letter are not significantly different $(\mathrm{P} \leq 0.05)$ for average grain yield.

$\mathrm{W}_{\mathrm{i}}$ : Lower values represent cultivars with higher stability. 
conditions. Further research, to estimate the connection between the photosynthetic performance index $\left(\mathrm{PI}_{\mathrm{ABS}}\right)$ measured in the early stage of growth, and WU, WUE, grain yield, and grain yield stability in field conditions, would be useful for breeding on stress tolerance.

Parameters of WU and $\mathrm{WUE}_{\mathrm{G}}$ could also be used as the last phase in testing of genotypes that already showed yield and quality potential in field trials, because they are much more cost effective methods for selection of drought tolerant genotypes as compared to multi-environmental and multi-annual field trials. Possibility of testing larger number of genotypes increases if we only use stress treatment to obtain necessary data, and acknowledged cultivars as standards to compare with.

\section{CONCLUSIONS}

Cultivars 'A11', 'A12', 'A13', 'A15', and 'A17' with higher values of grain yield based water use efficiency $\left(\mathrm{WUE}_{\mathrm{G}}\right)$ also had higher grain yield in both multienvironmental field trials. Taking into consideration high significant positive correlation coefficients between $\mathrm{WUE}_{\mathrm{G}}$ and grain yield per pot (GYP), it is possible that this parameter could indicate genotypes with potential for drought tolerance. Values of photosynthetic performance index $\left(\mathrm{PI}_{\mathrm{ABS}}\right)$ could not be connected with agronomic traits of grain yield, harvest index and biomass weight per pot, suggesting that barley cultivars were under low intensity drought stress conditions that had no influence on photosynthetic efficiency of tested barley cultivars. There are different approaches for defining water use efficiency by genotype, e.g. WUE for grain yield and WUE for biomass production. However, water use $(\mathrm{WU})$ and $\mathrm{WUE}_{\mathrm{G}}$ could be good indicators for preliminary selection of modern, high yielding and stable winter barley genotypes with better water management capabilities. Taking all into consideration, pot trials cannot substitute for multienvironmental field trials, but could be implemented as effective method for preliminary selection of desirable traits among numerous genotypes.

\section{ACKNOWLEDGEMENTS}

This paper is a part of the project entitled "Stress physiology and agricultural characteristics of wheat and barley cultivars" (073-073164-0552). The authors are grateful to the Ministry of Science, Education and Sport of the Republic of Croatia for the project support.

\section{LITERATURE CITED}

Akhter, J., S. Ali Sabir, Z. Lateef, M. Yaseen Ashraf, and M. Ahsanul Haq. 2008. Relationships between carbon isotope discrimination and grain yield, water-use efficiency and growth parameters in wheat (Triticum aestivum L.) under different water regimes. Pakistan Journal of Botany 40:1441-1454.
Altay, F. 2012. Yield stability of some Turkish winter wheat (Triticum aestivum L.) genotypes in the western transitional zone of Turkey. Turkish Journal of Field Crops 17:129-134.

Appenroth, K.J., J. Stockel, A. Srivastava, and R.J. Strasser. 2001. Multiple effects of chromate on the photosynthetic apparatus of Spirodela polyrhiza as probed by OJIP chlorophyll a fluorescence measurements. Environmental Pollution 115:49-64.

Araus, J.L., G.A. Slafer, C. Royo, and M.D. Serret. 2008. Breeding for yield potential and stress adaptation in cereals. Critical Reviews in Plant Sciences 27:377-412.

Balouchi, H.R. 2010. Screening wheat parents of mapping population for heat and drought tolerance, detection of wheat genetic variation. International Journal of Biological Life Sciences 6:56-66.

Bernacchi, C.J., B.A. Kimball, D.R. Quarles, S.P. Long, and D.R. Ort. 2007. Decreases in stomatal conductance of soybean under open-air elevation of $\left(\mathrm{CO}_{2}\right)$ are closely coupled with decreases in ecosystem evapotranspiration. Plant Physiology 143:134-144.

Bernacchi, C.J., A.D.B. Leakey, L.E. Heady, P.B. Morgan, F.G Dohleman, J.M. McGrath, et al. 2006. Hourly and seasonal variation in photosynthesis and stomatal conductance of soybean grown at future $\mathrm{CO}_{2}$ and ozone concentrations for 3 years under fully open-air field conditions. Plant Cell \& Environment 29:2077-2090.

Blum, A. 1993. Selection for sustained production in water deficit environments. p. 343-347. In Buxton, D.R., R. Shibles, RA. Forsberg, B.L. Blad, K.H. Asay, M. Paulsen, et al. (eds.) International Crop Science I. Crop Science Society of America (CSSA), Madison, Wisconsin, USA.

Blum, A. 2005. Drought resistance, water-use efficiency, and yield potential-are they compatible, dissonant, or mutually exclusive? Australian Journal of Agricultural Research 56:1159-1168.

Blum, A. 2009. Effective use of water (EUW) and not water-use efficiency (WUE) is the target of crop yield improvement under drought stress. Field Crop Research 112:119-123.

Boutraa, T. 2010. Improvement of water use efficiency in irrigated agriculture: A Review. Journal of Agronomy 9:1-8.

Bujak, H., K. Nowosad, and R. Warzecha. 2014. Evaluation of maize hybrids stability using parametric and non-parametric methods. Maydica 59:170-175.

Ceccarelli, S., S. Grando, R. Tutwiler, J. Baha, A.M. Martini, and H. Salahieh. 2000. A methodological study on participatory barley breeding I. Selection phase. Euphytica 111:91-104.

Doorenbos, J., and A.H. Kassam. 1979. Yield response to water. FAO Irrigation and Drainage Paper nr 33. FAO, Rome, Italy.

FAO. 2006. Guidelines for soil description. $4^{\text {th }}$ ed. 97 p. FAO, Rome, Italy.

Hejnák, V., B. Zámecníková, and J. Neckárová. 2011. The influence of high natrium and chlorine ion concentration on physiological responses of various spring barley varieties. Turkish Journal of Field Crops 16:93-98.

Huseynova, I.M., S.Y. Suleymanov, and M.S. Rustamova. 2010. Response of photosynthetic apparatus and antioxidant defense systems in Triticum aestivum L. genotypes subjected to drought stress. Proceedings of ANAS (Biological Sciences) 65(5-6):49-59.

Ilker, E., Ö. Tatar, F. Aykut Tonk, and M. Tosun. 2011. Determination of tolerance level of some wheat genotypes to post-anthesis drought. Turkish Journal of Field Crops 16:59-63.

Inostroza, L., H. Acuña, and J. Méndez. 2015. Multi-physiologicaltrait selection indices to identify Lotus tenuis genotypes with high dry matter production under drought conditions. Crop and Pasture Science 66:90-99.

Kovacevic, J., M. Kovacevic, V. Cesar, G. Drezner, A. Lalic, H. Lepeduš, et al. 2013. Photosynthetic efficiency and quantitative reaction of bread winter wheat to mild short-term drought conditions. Turkish Journal of Agriculture and Forestry 37:385-393. 
Kovacevic, J., M. Kovacevic, V. Cesar, A. Lalic, H. Lepedus, K. Dvojkovic, et al. 2011. Photosynthetic efficiency in juvenile stage and winter barley breeding for improved grain yield and stability. Agriculture 17:28-35.

Lalic, A., I. Abicic, J. Kovacevic, G. Simic, G. Drezner, D. Novoselovic, et al. 2012. Assessment of winter barley varieties under production conditions of the Republic of Croatia. Proceedings $289-293$. In $47^{\text {th }}$ Croatian and $7^{\text {th }}$ International Symposium on Agriculture, Opatija, Croatia. 13-17 February. University of Zagreb, Faculty of Agriculture, Zagreb, Croatia.

Lalic, A., J. Kovacevic, D. Novoselovic, G. Simic, I. Abicic, and V. Guberac. 2009. Agronomic and quantitative traits of winter barley varieties (Hordeum vulgare L.) under growing conditions in Croatia. Agriculturae Conspectus Scientificus 74:283-289.

Liu, Z.H., Z.B. Zhang, L.Y. Chu, and H.B. Shao. 2010. The corresponding relationship between roles of NADP-malic enzymes and abiotic stress in plants. Emirates Journal of Food and Agriculture 22:239-249.

Mohammadi, M., R. Karimizadeh, N. Sabaghnia, and M.K. Shefazadeh. 2012. Genotype $\times$ environment interaction and yield stability analysis of new improved bread wheat genotypes. Turkish Journal of Field Crops 17:67-73.

Oukarroum, A., S. El Madidi, G. Schansker, and R.J. Strasser. 2007. Probing the responses of barley cultivars (Hordeum vulgare L.) by chlorophyll a fluorescence OLKJIP under drought stress and rewatering. Environmental and Experimental Botany 60:438-446.

Passioura, J.B. 1977. Grain yield, harvest index and water use of wheat. Journal of the Australian Institute of Agricultural Science 43:117-120

Radin, J.W., W. Hartung, B.A. Kimball, and J.R. Mauney. 1988. Correlation of stomatal conductance with photosynthetic capacity of cotton only in a $\mathrm{CO}_{2}$-enriched atmosphere: Mediation by abscisic acid? Plant Physiology 88:1058-1062.

Reiner, L., V. Buhlmann, S. Graser, A. Heißenhuber, M. Klasen, V. Pfefferkorn, et al. 1992. Weizen Aktuell, Deutsche Landwirtshcaftliche Gesellschaft (DLG) Verlag, Frankfurt am Main, Deutschland.

Reynolds, M.P., M. Balota, M.I.B. Delgado, I. Amani, and R.A. Fischer. 1994. Physiological and morphological traits associated with spring wheat yield under hot, irrigated conditions. Australian Journal of Plant Physiology 21:717-730.

Reynolds, M.P., C. Saint Pierre, A.S.I. Saad, M. Vargas, and A.G. Condon. 2007. Evaluating potential genetic gains in wheat associated with stress-adaptive trait expression in elite genetic resources under drought and heat stress. Crop Science 47:172-189.

Romic, D., F. Tomic, D. Petosic, I. Stricevic, G. Ondrasek, and B. Rus. 2005. Hidropedoloska studija s idejnim rjesenjem navodnjavanja proizvodnih povrsina Poljoprivrednog instituta Osijek, Agronomski fakultet Zagreb, Zagreb, Croatia.

Shamsi, K., M. Petrosyan, G. Noor-Mohammadi, and R. Haghparast. 2010. The role of water deficit stress and water use efficiency on bread wheat cultivars. Journal of Applied Biosciences 35:2325-2331.
Shao, H.B., L.Y. Chu, Z.H. Lu, and C.M. Kang. 2008. Primary antioxidant free radical scavenging and redox signaling pathways in higher plant cells. International Journal of Biological Sciences $4: 8-14$.

Shao, H.B., Z.S. Liang, M.A. Shao, S.M. Sun, and Z.M. Hu. 2005. Investigation on dynamic changes of photosynthetic traits of 10 wheat (Triticum aestivum L.) genotypes during two vegetativegrowth stages at water deficits. Biointerfaces 43:221-227.

Siddique, K.H.M., D. Tennant, M.W. Perry, and R.K. Belford. 1990. Water use and water use efficiency of old and modern wheat cultivars in a Mediterranean-type environment. Australian Journal of Agricultural Research 41:431-447.

Siddiqui, Z.S., J.I. Cho, S.H. Park, T.R. Kwon, B.O. Ahn, G.S. Lee, et al. 2014. Phenotyping of rice in salt stress environment using high-throughput infrared imaging. Acta Botanica Croatica 73:149-158

Strasser, R.J., A. Srivastava, and G. Govindjee. 1995. Polyphasic chlorophyll a fluorescence transient in plants and cyanobacteria. Photochemistry and Photobiology 61:32-42.

Strasser, R.J., A. Srivastava, and M. Tsimili-Michael. 2000. The fluorescence transient as a tool to characterize and screen photosynthetic samples. p. 443-480. In Yunus, M., U. Pathre, and P. Mohanty (eds.) Probing photosynthesis: Mechanism, regulation and adaptation. Taylor and Francis, London, UK.

Talebi, R.F., F. Fayaz, and A.M. Naji. 2009. Effective selection criteria for assessing drought stress tolerance in durum wheat (Triticum durum Desf.) General and Applied Plant Physiology 35:64-74.

Tuberosa, R. 2012. Phenotyping for drought tolerance of crops in the genomic era. Frontiers in Plant Physiology 3:1-26.

Viets, F.G. 1962. Fertilizers and efficient use of water. Advances in Agronomy 14:233-264.

Vilhelmsen, A.L., M.P. Reynolds, B. Skovmand, D. Mohan, K.N. Ruwali, S. Nagarajan, et al. 2001. Genetic diversity and heritability of heat tolerance traits in wheat. Wheat Special Report nr 50. CIMMYT, Mexico D.F.

Wricke, G. 1962. Uber eine methode zur erfassung der okologischen streubreite in feldversuchen. Zeitschrift für Pflanzenzüchtung 47:92-96.

Yong'an, L., D. Quanwen, C. Zhiguo, and Z. Deyong. 2010. Effect of drought on water use efficiency, agronomic traits and yield of spring wheat landraces and modern varieties in Northwest China. African Journal of Agricultural Research 5:1598-1608.

Zhang, X., S. Chen, H. Sun, Y. Wang, and L. Shao. 2010. Water use efficiency and associated traits in winter wheat cultivars in the North China Plain. Agricultural Water Management 97:1117-1125. 